\title{
Preliminary Study on Non-Fatal Occupational Injury among Operational Workers in Malaysia Palm Oil Mill
}

\author{
Rumaizah Ruslan ${ }^{1, *}$, Ishak Baba ${ }^{1}$, and Abdul Mutalib Leman ${ }^{1}$ \\ ${ }^{1}$ Faculty of Engineering Technology, Universiti Tun Hussein Onn Malaysia, 86400 Parit Raja Batu \\ Pahat, Johor, Malaysia
}

\begin{abstract}
Non-fatal occupational injury had becoming major global concern and its consequences to safety and health would be heavily burdening. The aim of this preliminary study was to investigate the distribution of non-fatal occupational injury among specific group of workers in palm oil mill and to acknowledge potential factors of injury causation. A questionnaire survey was designed to assess injury involvement during the employment period among operational workers of palm oil mill located in Southern Peninsular Malaysia. Thirty three $(n=33)$ workers volunteered and completed the questionnaire. Prevalence of injury among palm oil mill workers was $39.4 \%$ with sprain and burn were the common types of injury reported. Press Plant workers reported to have high cases of injuries. Majority of workers $(78.8 \%)$ stated noise was the main hazard in the palm oil mill, followed by heat hazard. Press Plant was identified as one of the specific risk group in palm oil mill based on the rate of injury occurrences reported by the workers. Exposure to noise hazard was estimated to be one of the potential factors of injury causation and further study should be made to measure the risk of hazard.
\end{abstract}

\section{Introduction}

Non-fatal occupational injury is defined by as any condition that resulted in 4 hours or more of restricted activity; for example a person could not perform work or other normal duties, missed work, or a condition that required professional medical treatment [1]. For the purpose of this study, non-fatal occupational injury could be defined as a damaged to human body resulting from working activities, which involve with or without sick leave, ranges from negligible injury to permanent disability among workers of palm oil mill industry. The importance of injuries in low- and middle-income contexts is expected to increase, and by 2020 injury will rank as the second major contributor to disability adjusted life year (DALY) loss [2]. Compared to other health conditions, the physical, psychological and social impacts of injuries are a relatively new area of study. However, initial accounts suggest that the impact of injuries is staggering [2]. Injuries could lead to the loss of the

* Corresponding author: rumaizah@uthm.edu.my 
individual's future social and economic contribution, and the permanent loss of the usually considerable material and human resources already invested in education and development [3].

In Malaysia, it was noted the highest annual average incidence rate of non-fatal occupational injuries in the agricultural sector $(24.1 / 1000)$ in the year 2011. The main types of injuries reported were superficial injuries $(17 \%)$, followed by sprains and strains $(10 \%)$ and fractures $(5 \%)$. Falling from heights $(31 \%)$ was the main cause of accidents followed by being struck by objects $(25 \%)$. The main accident agent was identified as working environment (45\%) [4]. Research on health and safety related to palm oil workers in Malaysia have vigorously been done based on published articles in recent years [5 - 11]. The findings had proven that health and safety issue among palm oil workers is required full attention and commitment. Neglecting health and safety aspects which are included for social wellbeing, may affect the sustainability of palm oil industry. However, lack attention had been paid for occupational injuries issues in local palm oil mill due to narrow references of related research that focusing in milling factory. Hence, this paper was aimed to explore the distribution of nonfatal occupational injuries among palm oil mill workers by estimating the prevalence rate of injury, types of injury based on their workstations, to identify workers' perception of workplace hazards and to determine high risk group of worker based on injury by workstations.

\section{Methods}

\subsection{Subject and study population}

This preliminary research had took place in one of the palm oil mill in Southern Peninsular Malaysia, with 33 operational workers were volunteered in assisted questionnaire session. All workers involved in this research were Malaysian.

\subsection{Questionnaire}

Set of questionnaires were distributed to the respondents for gaining workers' information and potential risk factors, perceived workplace hazards and injury due to hazard exposure at the workplace. The questionnaire session was carried out with the assistance of the mill supervisor for the purpose of gathering information from the respondents. The management personnel of the palm oil mill were adequately informed and were aware of the purpose of the study. They were also made to understand that participation in the study was voluntary and under a strict confidentiality.

\subsection{Data analysis}

This pilot study was to explore the preliminary results of nonfatal occupational injury among workers in palm oil mills. Hence, statistical analysis involved in this study will only contain descriptive data outcome. This is due to recommendation by other authors in past literature $[12,13]$ which stated any type of pilot study should be mainly descriptive. Although the outcome from a pilot study provided with relevant information, but hypothesis testing should be interpreted with caution. The two main reason of this are because of the limited state of knowledge about the methods and the smaller proposed sample size [14]. 
In this paper, the preliminary results were accumulated from profiling data of respondent's epidemiological data consists of socio-demographic information, working profile, lifestyle, health status and injuries information. Details of the profiling data used in this study were explained in authors' previous paper [15].

\section{Results}

\subsection{Socio-demographic data and work profile}

All respondents who volunteered to participate in this pilot study were Malaysian male operational workers in palm oil mill. There were about 33 feedbacks were gained in form of complete answered questionnaire. For reliability test, these questionnaires were tested with Cronbach's $\alpha$ value of 0.827 . The accepted alpha value more than 0.70 reveals that the inter-item for measurement items in a construct is consistent [16-18].

The respondents' age ranges were around 18 to 57 years old. Most of them $(69.7 \%)$ have received and completed formal education until secondary schools. They are working six (6) days a week from Sunday to Friday with an average of 8 hours of working a day. All of them are reported to have an overtime period of working in the mill, with majority (63.6\%) claimed to have more than 5 times overtime in a month. The workstations of the respondents varies from Loading Ramp, Sterilizer, Press Plant, Kernel Plant, Boiler Room, Engine Room, Oil Room, lab workers and grader workers.

\subsection{Non-fatal occupational injury information}

Non-fatal occupational injury information was obtained through an active survey and included in the research's questionnaire. The information of injuries was adapted from the WHO Injury Surveillance Guideline [19]. Out of 33 respondents, thirteen (13) of them claimed that they had experienced injury while working in the mill. The prevalence rate for injury occurrences among operational workers in palm oil mills was $39.4 \%$ as in Table 1 . The highest rate of injury occurrences was among workers who work at press plant and other workstations such as Engine Room, Oil Room, lab and grader workers.

Table 1. Number of injured workers based on workstations.

\begin{tabular}{|c|c|c|c|}
\hline Workstations & Respondents & $\begin{array}{c}\text { Injured workers } \\
\text { n (\%) }\end{array}$ & $\begin{array}{c}\text { Noise hazard } \\
\text { reported }\end{array}$ \\
\hline Loading ramp & 9 & $0(0 \%)$ & $4(12.1 \%)$ \\
\hline Sterilization & 1 & $0(0 \%)$ & $1(3 \%)$ \\
\hline Press plant & 5 & $5(15.2 \%)$ & $4(12.1 \%)$ \\
\hline Kernel plant & 3 & $1(3.0 \%)$ & $3(9.1 \%)$ \\
\hline Boiler room & 2 & $2(6.1 \%)$ & $2(6.1 \%)$ \\
\hline $\begin{array}{c}\text { Others (engine } \\
\text { room, oil room, lab } \\
\text { and grader } \\
\text { workers) }\end{array}$ & 13 & $5(15.2 \%)$ & $12(36.4 \%)$ \\
\hline Total & 33 & $13(39.4 \%)$ & $26(78.8 \%)$ \\
\hline
\end{tabular}


Average age of injured workers was around 25 years old. The common type of injuries were sprain (30.8\%), burn (30.8\%) and followed by major cut and scratches (15.4\%). Most of workers claimed that injuries were caused by falling (46.2\%) and sharp object (30.8). Lower body was reported to be main body part affected due to the injuries $(30.8 \%)$. Severity and frequency of non-fatal occupational injury were measured based on the respondents' self-report. Majority of them experienced moderate injury (30.3\%) and there was no repetition of the same injury at the same year which was indicated by less than one injury occurrences in a year. Table 2 summarized the results.

Table 2. Socio-demographic of injured workers and characteristics of injuries.

\begin{tabular}{|c|c|c|c|c|c|}
\hline Variables & Characteristics & $\begin{array}{c}\text { Frequencies } \\
\text { (n) }\end{array}$ & $\begin{array}{c}\text { Proportion } \\
(\%)\end{array}$ & $\begin{array}{c}\text { Mean } \pm \\
\text { SD }\end{array}$ & Range \\
\hline Age & & - & - & 25.46 & 7.253 \\
\hline $\begin{array}{l}\text { Work } \\
\text { Profile }\end{array}$ & $\begin{array}{c}\text { Month of employment } \\
\text { Month of employment in } \\
\text { the work station }\end{array}$ & - & - & $\begin{array}{l}19 \\
22 \\
\end{array}$ & $\begin{array}{l}11.762 \\
11.080\end{array}$ \\
\hline $\begin{array}{l}\text { Type of } \\
\text { injury }\end{array}$ & $\begin{array}{c}\text { Sprain } \\
\text { Burn } \\
\text { Major cuts and } \\
\text { scratches } \\
\text { Minor cuts and } \\
\text { scratches } \\
\text { Bruise } \\
\text { Uncertain }\end{array}$ & $\begin{array}{l}4 \\
4 \\
2 \\
1 \\
1 \\
1\end{array}$ & $\begin{array}{l}30.8 \\
30.8 \\
15.4 \\
7.7 \\
7.7 \\
7.7\end{array}$ & $\begin{array}{l}- \\
- \\
- \\
- \\
-\end{array}$ & $\begin{array}{l}- \\
- \\
- \\
- \\
-\end{array}$ \\
\hline $\begin{array}{l}\text { Mechanis } \\
\mathrm{m} \text { of injury }\end{array}$ & $\begin{array}{c}\text { Falling } \\
\text { Sharp object } \\
\text { Bang/beaten by object } \\
\text { Fire/Fire smoke } \\
\text { Others }\end{array}$ & $\begin{array}{l}6 \\
4 \\
1 \\
1 \\
1\end{array}$ & $\begin{array}{l}46.2 \\
30.8 \\
7.7 \\
7.7 \\
7.7\end{array}$ & $\begin{array}{l}- \\
- \\
- \\
- \\
-\end{array}$ & $\begin{array}{l}- \\
- \\
- \\
- \\
-\end{array}$ \\
\hline $\begin{array}{l}\text { Body part } \\
\text { effected }\end{array}$ & $\begin{array}{c}\text { Lower part of body } \\
\text { Upper part of body } \\
\text { Head } \\
\text { Face } \\
\text { In various part of body }\end{array}$ & $\begin{array}{l}4 \\
3 \\
3 \\
1 \\
1\end{array}$ & $\begin{array}{c}30.8 \\
23.1 \\
23.1 \\
7.7 \\
7.7\end{array}$ & $\begin{array}{l}- \\
- \\
- \\
-\end{array}$ & $\begin{array}{l}- \\
- \\
- \\
-\end{array}$ \\
\hline Severity & $\begin{array}{c}\text { First aid } \\
\text { Moderate injury } \\
\text { Major injury }\end{array}$ & $\begin{array}{c}2 \\
10 \\
1\end{array}$ & $\begin{array}{c}6.1 \\
30.3 \\
3.0\end{array}$ & & \\
\hline $\begin{array}{l}\text { Frequency } \\
\text { of injury }\end{array}$ & $\begin{array}{c}\text { Less than one in a year } \\
\text { Once in a month } \\
\text { Once in a week } \\
2-3 \text { times a week }\end{array}$ & $\begin{array}{c}10 \\
1 \\
1 \\
1\end{array}$ & $\begin{array}{c}30.3 \\
3.0 \\
3.0 \\
3.0\end{array}$ & & \\
\hline
\end{tabular}

$n=13$

\subsection{Reported self-perceived hazards at the workplace}

Hazard at workplace had been determined based on perception of workers while they are working at the mill. Those hazards were rank based on the frequency and the result is shown in the Fig. 1. Majority of workers reported noise (78.8\%) was the main hazards in their workplace. The distribution of self-perceived hazards was further analysed by focusing on injured workers. Results as illustrated in Fig. 1 showed that majority of injured workers claimed that they are exposed by noise hazard (92.3\%), followed by dust exposure and slippery floor $(61.5 \%$, respectively). Majority of workers reported noise $(78.8 \%)$ was the main hazards in their workplace. 


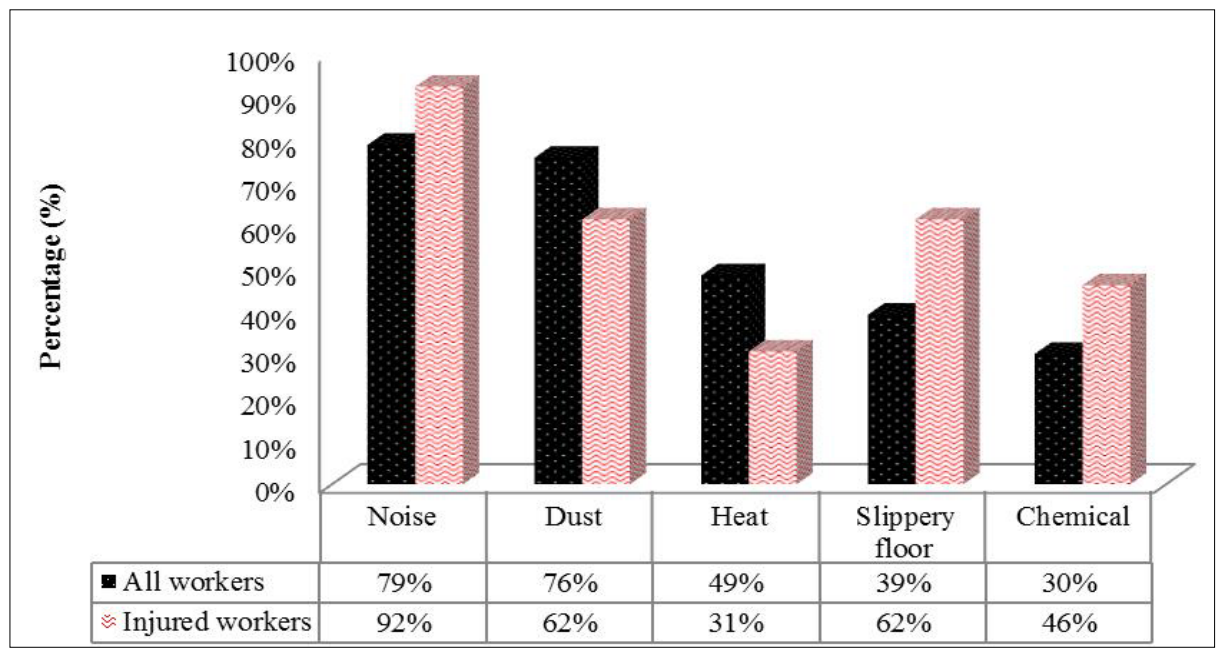

Fig. 1. Distribution of self-perceived hazards at workplace.

\subsection{High risk group of nonfatal occupational injuries based on different workstation in palm oil mill}

High risk group was determined based on the descriptive distribution of nonfatal occupational injury cases with regards to the respondents' workstation. According to the result as illustrated in Table 1, respondents worked in the press plant and others section had high percentage of injury reported (15.2\%). Self-perceived noise hazard for Press plant was $12.1 \%$ and for others section was $36.4 \%$. Meanwhile workers of boiler room revealed the same percentage for both parameters of injury (6.1\%) and reported noise hazard (6.1\%).

\section{Discussions}

This study had found out that majority of injured workers were around 25 years old. As stated in previous literature review [20], workers who aged under 25 years old is consider as young workers. He added that the majority of studies on nonfatal injuries showed that young workers had a higher injury rate than the overall rate. This result is align with other recent study which stated workers aged less than 30 years old is commonly reported to have injury $[21,22]$.

Prevalence of injury was $39.4 \%$ with workers in Press plant reported high incidents of injuries. The findings estimated out of 100 operational workers in palm oil mill, 39 of them had injured during work. Handling the press and digester machine were among the job tasks that had to be accomplished by Press Plant workers. Their work intensively involved in hand movement and walking. Common injury was determined to be sprain (30.8\%), burn $(30.8 \%)$, major cut and scratches $(15.4 \%)$. These findings had proven that workers in palm oil mills are heavily engaged with physical movement, walking and working at height, which could cause sprain injury. Palm oil mill workers exposed to heat due to job process in palm oil production where mainly the processes were in contact with hot machinery. The reason had explained the cause of burn injury that commonly reported by the workers in this study. However, the findings contradict with previous research conducted in Malaysia where the main types of injuries reported were superficial injuries $(17 \%)$, followed by 
sprains and strains (10\%) and fractures (5\%) [4]. This might be due to different scope of industry, where this study specifically focused on palm oil mill workers rather than general workers in various agricultural industries.

The determinants of injury are relying on descriptive analysis, which the analysis can be used to generate hypotheses of association between exposures and outcomes. In this study, majority of workers reported to be interfered by noise during work. Moreover, greater figure of injured workers claimed to have exposed to noise compared to other hazards. Thus the direction of future study will be carried out by having an initial hypothesis, which is to measure the impact of noise exposure to occupational injuries. These had been supported by past research that stated risk of workplace injury correlated with noise exposure based on a dose-response relationship [23].

\section{Conclusions}

Younger workers which aged around 25 years old had a higher risk of non-fatal occupational injury in palm oil mill. Press Plant was identified as one of the risk group in palm oil mill based on the rate of injury occurrences reported by the workers. The common injuries were sprain and burn. Exposure to noise hazard was estimated to be one of the potential factors of injury causation and further study should be made to measure this risk of hazard.

This study was funded by the Office of Research, Innovation, Commercialization and Consultancy Management (ORICC) Universiti Tun Hussein Onn Malaysia under Multidicplinary Research Grant Scheme (Project No: U099). The authors would like to thank the management and respondents of palm oil mill who involved in the study.

\section{References}

1. Information on http://www.cdc.gov/niosh/programs/expa/A.V. Niekerk, N. Duncan, ASP, 1-4 (2002)

2. P. Barss, G. Smith, S. Baker, D. Mohan: Injury Prevention: An International Perspective, (Oxford University Press, New York, 1998)

3. L. Abas, A.R.B.M. Said, M.A.B.A. Mohammed, N. Sathiakumar, Int. J. Occup. Environ. Health, 17 (2011)

4. S.G. Normala, K.M. Dileep, S.R. Subrahmanium, Asian Social Science, 10 (2014)

5. Y.G. Ng, S.B.M. Tamrin, W.M. Yik, I.S.M. Yusoff, I. Mori, Industrial Health, 52 (2014)

6. Y.G. Ng, S.B.M. Tamrin, Y.I. Shah, I. Mori, Z. Hashim, J. Occup. Health, 55 (2013)

7. E.H. Sukadarin, B.M. Deros, J.A. Ghani, A.R. Ismail, M.M. Mokhtar, D. Mohamad, Advanced Engineering Forum, 10 (2013)

8. N.D.M. Yusof, K. Karrupiah, S.B.M Tamrin, Adv. Environ. Biol., 8 (2014)

9. H.M. Hadi, S.B.M. Tamrin, K. Karrupiah, Adv. Environ. Biol., 8 (2014)

10. R.L. Naeini, S.B.M. Tamrin, Asian J. Med. Pharm. Res., 4 (2014)

11. A. Bauhofer, B. Stinner, U. Plaul, A. Torossian, M. Middeke, I. Celik, M. Koller, W. Lorenz, Br. J. Surg., 88 (2001)

12. G. Lancaster, S. Dodd, P. Williamson, J. Eval. Clin. Pract.,10 (2004)

13. A. Leon, L. Davis, H. Kraemer, J. Psychiatr. Res., 45 (2011)

14. R. Ruslan, I. Baba, A. M. Leman, T. L. Wai, ARPN Journal of Engineering and Applied Sciences, 11 (2016) 
15. M. F. Ahmad: Basic Statistical Analysis: Step by Step Using SPSS (Penerbit UTHM, Johor, 2016)

16. J.F. Hair: Multivariate Data Analysis (Pearson Prentice Hall, New York, 2010)

17. J.C. Nunnally: Psychometric Theory (McGraw-Hill, New York, 1978)

18. Y. Holder, M. Peden, E. Krug, J. Lund, G. Gururaj, O. Kobusingye: Injury Surveillance Guideline (World Health Organization, Geneva, 2001)

19. S. Salminen, J. Safety Res., 35 (2004)

20. S.G. Kumar, A. Dharanipriya, Indian J. Occup Environ Med, 18 (2014)

21. S.G. Kumar, U. Rathnakar, H. Harsha Kumar, Indian J. Community Med., 35 (2010)

22. J.H. Yoon, J.S. Hong, J. Roh, C.N. Kim, J.U. Won, Noise Health, 17 (2015) 